\title{
THE PROBLEMS OF DATING NON-ATTIC CLASSICAL KANTHAROI
}

\author{
Tatyana V. Egorova \\ Lomonosov Moscow State University, Moscow, Russian Federation
}

\begin{abstract}
The article is devoted to analyzing the problems of dating classical kantharoi produced in the workshops of Asia Minor, Macedonia, Thessaly, Thrace and other ancient centers of the last third of the $4^{\text {th }}$ - the middle - end of the $2^{\text {nd }} \mathrm{c}$. BC. These problems are closely related to the issues of identifying centers of their production. The formulation and resolution of these issues have aroused an increased interest recently. The article presents the main characteristics of classical kantharos forms depending on time and center of their manufacture. The paper collects information on published fragments and whole vessels and publishes for the first time five late non-attic kantharoi found on the territory of Panticapaeum and Tanais. Besides, it considers general trends and features in the development of such forms. The morphological comparison of non-attic kantharoi and their attic prototypes makes it possible to draw a conclusion on their synchronous development. The analysis of forms and proportions of two of the three main varieties of kantharoi, which belong to the Pontic Hellenistic ceramics group, as well as their contexts including sites in the North Pontic region, gives us the possibility to follow the form transformation in the direction of changing proportions, namely, their profile elongation and/or gradual body decrease in the third quarter of the $3^{\text {rd }}$ - the beginning/middle of the $2^{\text {nd }} \mathrm{c}$. BC. In addition, it allows to trace in the third variant the further development of the form to the complete body schematization, which appeared in the middle or the third quarter of the $2^{\text {nd }} \mathrm{c}$. BC.

Key words: the North Pontic region in the Hellenistic time, antique ceramics, production of black-varnished vessels, kantharoi, chronology.

Citation. Egorova T.V., 2019. The Problems of Dating Non-Attic Classical Kantharoi. The Lower Volga Archaeological Bulletin, vol. 18, no. 1, pp. 123-137. (in Russian). DOI: https://doi.org/10.15688/nav.jvolsu.2019.1.10

УДК 902(652):641.546

Дата поступления статьи: 01.02.2019

ББК 63.443.21-414

Дата принятия статьи: 06.03.2019
\end{abstract}

\section{ПРОБЛЕМЫ ДАТИРОВАНИЯ НЕАТТИЧЕСКИХ КАНФАРОВ КЛАССИЧЕСКИХ ФОРМ}

\section{Татьяна Валерьевна Егорова}

Московский государственный университет им. М.В. Ломоносова, г. Москва, Российская Федерация

Аннотация. Статья посвящена анализу проблем датирования канфаров классических форм, выпускавшихся в мастерских Малой Азии, Македонии, Фессалии, Фракии и других античных центров с последней трети IV до середины - конца II в. до н.э. Эти проблемы тесным образом связаны с вопросами выявления центров их изготовления, к постановке и решению которых в последнее время наблюдается повышенный интерес. В статье даны основные характеристики форм классических канфаров в зависимости от времени и центра их производства. Собраны сведения об опубликованных фрагментах и целых сосудах, а также впервые публикуются пять поздних неаттических канфаров, найденных на территории Пантикапея и Танаиса. Рассматриваются общие тенденции и особенности в их развитии. Морфологическое сравнение неаттических канфаров с их аттическими прототипами дает возможность сделать вывод об их синхронном развитии. Анализ форм и пропорций двух из трех основных вариантов канфаров, относящихся к группе Понтийской эллинистической керамики, а также контекстов, в которых они были найдены, в том числе на памятниках, расположенных в Северном Причерноморье, позволил проследить трансформацию формы в сторону изменения () пропорций, а именно вытягивания профиля и/или постепенного уменьшения объема тулова в хронологи- 
ческий промежуток от третьей четверти III до начала - середины II в. до н.э., а также проследить в третьем варианте дальнейшее развитие формы к полной схематизации тулова, появившейся в середине или третьей четверти ІІ в. до н.э.

Ключевые слова: Причерноморье в эллинистическое время, античная керамика, производство чернолаковой посуды, канфары, хронология.

Цитирование. Егорова Т. В., 2019. Проблемы датирования неаттических канфаров классических форм //Нижневолжский археологический вестник. Т. 18, № 1. С. 123-137. DOI: https://doi.org/10.15688/nav.jvolsu.2019.1.10

Чернолаковые канфары классических форм относятся к одному из наиболее популярных типов сосудов для питья, использовавшихся на территории античного мира с середины IV до середины III в. до н.э., хотя время их производства укладывается в более широкие хронологические рамки от второй четверти IV до II в. до н.э. [Sparkes, Talcott, 1970, p. 122; Rotroff, 1997, p. 83-85; Bozkova, 1997, p. 9; Егорова, 2009, c. 24-28; Schäfer, 1968, S. 33-42; Drougou, 1991 , p. 140; и др.]. Для этой формы сосудов характерны глубокое вместилище с резким делением на высокое горло и гладкое или каннелированное тулово, вертикальные ручки и профилированная ножка на более или менее высоком стволе, в некоторых случаях - профилированный поддон. В значительном количестве их производили в аттических мастерских, и масштабы этого производства поистине поражают, если учитывать процент их встречаемости не только в Средиземноморье, но и в Причерноморье как на греческих, так и на варварских памятниках [Егорова, 2009, с. 137, 138; Лимберис, Марченко, 2017; и др.]. С этим в значительной степени связан тот факт, что хронология аттических канфаров довольно хорошо разработана [Robinson, 1950, p. 274-294; Sparkes, Talcott, 1970, p. 122; Rotroff, 1984, p. $348-349$; 1997, p. 83-85; Егорова, 2000, c. $137-145 ; 2009$, c. 25,26$]$.

На данный момент на основании сопоставления морфологии чернолаковых сосудов и ареометрических анализов глин можно считать установленным, что их выпуск был налажен не только в Аттике, несомненно лидировавшей по количеству таких изделий, но и в некоторых других античных центрах [Bozkova, 2005; 2014, p. 211; Drougou, Touratsoglou, 1991;

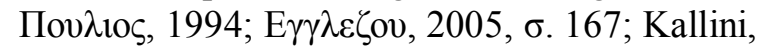
2013, p. 60-62; Lungu, 2013, p. 56-57, 288-289; Bulut, 2013, p. 81].
Несмотря на то что наибольшее внимание исследователей привлекала тема, связанная со временем изготовления неаттических чернолаковых канфаров эллинистических форм, в частности с S-видным профилем (подробнее: [Егорова, 2017]), вопрос о датировании канфаров классических форм, выпускавшихся за пределами Аттики, также поднимался в литературе [Bozkova, 1997, p. 9; 2014, p. 211; Kallini, 2013, p. 59-65]. Однако до сих пор эти темы остаются дискуссионными. По всей видимости, они тесным образом связаны с проблемами выявления центров их производства, к постановке и решению которых в последнее время наблюдается повышенный интерес.

К настоящему времени с высокой степенью достоверности выявлены несколько центров, расположенных на территории Аппенинского полуострова, Малой Азии, Македонии, Фессалии, Фракии и некоторых островов бассейна Эгейского моря. Вплоть до середины - третьей четверти III в. до н.э. здесь выпускали канфары классических форм параллельно аттическим образцам. Вероятнее всего, их изготавливали главным образом для внутреннего использования и в меньшей степени на экспорт.

Довольно большую группу из них составляют южноиталийские канфары (рис. 1,1-3), формы которых первоначально также развивались параллельно аттическим, но очень рано (уже в IV в. до н.э.) направление их развития существенно меняется [Stanko, 2004, p. 32; Morel, 1987, p. 112; Hayes, 1984, p. 49, 69; и др.]. Поскольку на памятниках Северного Причерноморья они практически не встречаются, в этой статье мы не будем подробно на них останавливаться.

Исследования материалов, в первую очередь из некрополей Северной Греции, позволили сделать выводы о том, что подражания аттическим канфарам появляются здесь уже 
в последние десятилетия IV в. до н.э., а возможно и около середины этого столетия

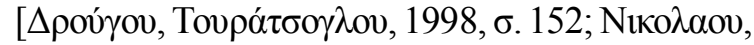

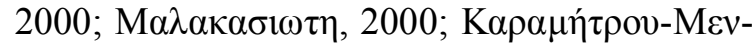

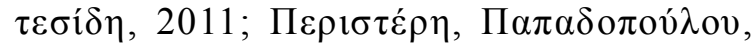
Гарои́ $\alpha, 2018$, б. 291-297; и др.]. Это самые ранние, зафиксированные на данный момент подражания, за исключением сосудов, происходящих с территории Великой Греции. Их производство продолжалось вплоть до середины II в. до н.э. Группа изделий, выпускавшаяся одновременно с аттическими, то есть до третьей четверти III в. до н.э., отличается тем, что представляет собой довольно точную имитацию аттических прототипов (рис. 1,4-6) как в части пропорций, так и ор-

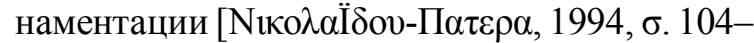
105, đív. 50, 51; Lungu, 2013, p. 288, 289, pl. 16,

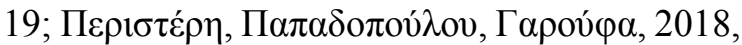
б. 291-297, 304, 305, 307; Kallini, 2013, p. 59]. Новые публикации закрытых комплексов, в частности раскопанных еще в 80-90-е гг. прошлого века в западной части префектуры Каваллы (Восточная Македония) и датированных на основании многочисленных находок монет (более 107) и фазосских амфор, дают основания исследователям, занимавшимся вопросами хронологии македонской чернолаковой керамики, делать выводы о том, что развитие местных форм, связанное в первую очередь с изменениями пропорций канфаров, происходит абсолютно аналогично аттичес-

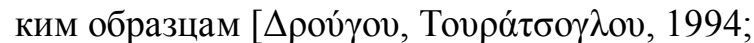

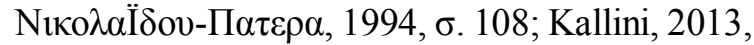
p. 59-62].

Сходные тенденции выявляются при анализе сосудов, изготавливавшихся в мастерских, расположенных на территории Фракии и севернее, к изучению хронологии которых неоднократно обращалась А. Божкова [Bozkova, 1997 , p. 9; 1997a; 2005, p. 46-49; 2014, p. 210 211] (рис. 1,7-8). Здесь они появляются не ранее начала второй четверти III в. до н.э.

Еще одним, пожалуй, самым мощным центром производства чернолаковой керамики в эллинистическое время была Малая Азия. Мастерские могли располагаться в районе Пергама-Кестеля, Эфеса, Даскилеона или прибрежных городов Геллеспонта [Schäfer, 1968, S. 28; Japp, 2009, S. 193-210; Bulut, 2013, p. 81]. Необходимо отметить, что гораздо больше известны малоазийские канфары эллинистических форм, широко представленные на северопричерноморских памятниках [Behr, 1988 , p. 113; Bulut, 2013, p. 83-85; ПаровичПешикан, 1974, с. 77-78; Зайцев, 1998, с. 57, 58; Егорова, 2009, с. 48-49; Сапрыкин, Внуков, 2015, с. 112-113; и др.]. Однако на основе археометрических исследований последних лет была выделена и группа малоазийских канфаров классических форм, близких аттическим образцам (рис. 1,8-11,13). Дата производства таких канфаров, найденных в Истрии, определяется в пределах второй - третьей четвертей III в. до н.э. [Lungu, 2013, p. 194-198], в Даскилеоне они датируются до конца III столетия [Bulut, 2013, p. 76].

Подобные канфары с аналогичными характеристиками глины находят и в Северопричерноморском регионе в слоях первой половины ІІІ в. до н.э. (подробнее: [Егорова, 2009, c. 47-48]). Для всех этих сосудов зачастую отличия можно уловить только на уровне характеристики глин, и то далеко не всегда, если использовать исключительно визуальный анализ. Так, традиционно считается, что для глиняного теста аттических чернолаковых изделий характерны различные оттенки бежевого или оранжевого тонов (Munsell: 7.5 YR 6/6, 7/ 4, 8/6; 10YR 7/4), малоазийских - оттенки красного (Munsell: 2,5 YR 6/6, 6/8, 7/6) и красно-желтого тона (Munsell: 5 YR 6/6, 6/8, 7/6; 7,5 YR 7/6, 7/8, 8/6), македонских и фракийских - светло-красного, красновато-коричневого или серого цвета (для них исследователи не указывают соответствия таблице Манселла, ограничиваясь простым описанием).

Особняком стоит группа канфаров, сильно отличавшаяся от представленных выше, прежде всего, формой ручек и отсутствием профилировки поддона (рис. 1,12). По всей видимости, она производилась в одном из центров Фессалии в конце IV - первой трети III в. до н.э., судя по сопутствующему инвентарю в одном из погребений некрополя Алоса [М $\alpha \lambda \alpha \kappa \alpha \sigma \iota \omega \tau \eta, ~ 2000$, б. 150-151].

Однако выпуск канфаров классических форм в Аттике был практически прекращен около середины - третьей четверти III в. до н.э. В Афинах, в слоях, относящихся к этому времени, находят только единичные образцы [Rotroff, 1997, p. 84]. В первую очередь это 
было связано с общими изменениями столового набора, происходившими постепенно с начала III в. до н.э., и наиболее отчетливо проявившимися в 60-40-е гг., что отмечает в одной из своих работ Кшиштов Домжальский, анализируя эти события в свете изменений импортов в Понтийский регион [Domżalski, 2007, p. 161-181]. В частности, именно в это время появляются новые, так называемые эллинистические формы канфаров, производившиеся в разных вариантах как в Аттике, так и далеко за ее пределами и постепенно вытеснившие классические типы.

После прекращения выпуска аттических классических канфаров в других центрах тем не менее продолжили их изготовление. Вполне естественно, что формы этих сосудов начали постепенно трансформироваться, все больше отдаляясь от первоначальных образцов. И здесь закономерно встают вопросы их хронологии, которые в значительной степени пока остаются открытыми по двум основным причинам. Во-первых, это отсутствие достаточного количества узко датированных закрытых комплексов с их находками, особенно если говорить о Северном Причерноморье, где часто исследователи датируют слои и объекты, напротив опираясь на аналогии подобным сосудам. Во многих публикациях эти даты весьма широки (III-II вв. до н.э.). Во-вторых, это значительное разнообразие таких форм.

Очевидно, что даже во второй половине III в. до н.э. аттические канфары продолжали оставаться основными образцами для подражания, а также базой для дальнейшего развития формы. И наиболее близкие им по пропорциям сосуды, сделанные в одном или нескольких центрах Малой Азии, в Македонии, Фессалии и Фракии, на островах бассейна Эгейского моря и в Западном Причерноморье, не отстояли от них далеко в хронологическом плане, хотя и уходили уже во вторую половину и конец III, а возможно и начало II столетий, судя по контекстам некоторых находок.

Так, продолжающие развитие классических форм канфары македонского производства С. Дрогу и И. Тоуратсоглу на основании анализа погребальных комплексов некрополя Берои датируют концом III - началом II в. до н.э. [Drougou, Touratsoglou, 1991, p. 13-17]. Выделяется два основных варианта таких канфаров.
Первый (тип С по С. Дрогу) - на кольцевом поддоне вместо ножки (рис. 2,1). Один из таких канфаров имеет хорошую дату по сопутствующему материалу из погребения IV в некрополе античного Лонгоса (Северная Греция) - конец III в. до н.э. [Drougou, 1991, p. 129]. Второй (тип В по С. Дрогу) - на ножке, но, в отличие от аттических прототипов, с измененной конфигурацией нижней части тулова и ручек, визуально формирующих подбиконические очертания сосуда (рис. 2,3,4). Они также датируются последними десятилетиями III - началом II в. до н.э. [Drougou, Touratsoglou, 1980, p. 100, pl. 66; Поvגıs, 1994, б. 116].

Эпизодически близкие к ним по формам сосуды встречаются на разных памятниках Северного Причерноморья, но преимущественно во фрагментах, по которым без проведения соответствующих анализов зачастую довольно сложно их атрибутировать.

Форма еще одной группы канфаров гораздо больше отличается от классической, делая их ближе некоторым чашам эллинистических типов из Аттики (см., например: [Niко $\alpha$ ov, 2000, б. 50-51]). Это сосуды с невысоким цилиндрическим горлом и объемным каннелированным туловом, с вертикальными ручками, украшенными ротелями или стилизованными выступами-шипами (рис. 2,4-7). Один из таких канфаров В. Лунгу отнесла к малоазийскому производству, проводя анализы глин керамики West Slope, найденной при раскопках Истрии [Lungu, 2013, p. 288, pl. 17]. Продукцией местных мастерских их считает и Ю. Булут в публикации материалов из Даскилеона [Bulut, 2013, p. 81, fig. 1]. Аналогичные сосуды были обнаружены при раскопках мастерских Нисикёй и Зейтинлик близ Синопы, где также предположительно атрибутировались как местные изделия и датировались не позднее чем III в. до н.э. [Sökeli, 2013, p. 126]. Идентичные по форме канфары встречались в Ольвии, Херсонесе и на территории его хоры [Парович-Пешикан, 1974, с. 78-79; Bouzek, 1990, p. 54-60, fig. 14,2; Hannestad, Stolba, Hastrup, 2002, p. 134, pl. 70; Буравчук, 2014, с. 367; Лепер, 1927, с. 229; Егорова, 2009, c. 233]. Авторы публикаций ольвийских материалов отнесли их предположительно к причерноморскому производству вслед за А. Божковой, которая выделяла их в тип II группы 
понтийской керамики [Bozkova, 1997, p. 11, fig. 5]. Однако на данном этапе исследований вопрос о месте их производства остается открытым. Опираясь на ольвийские материалы, исследователи предлагали только очень широкую дату - конец III - II в. до н.э. Хотя надо отметить, что уже М. Парович-Пешикан писала, что один из таких канфаров был найден в погребении с монетой конца III в. до н.э. [Парович-Пешикан, 1974, с. 80]. В. Лунгу и Ю. Булут датируют их так же широко - от последней четверти III до 30-х гг. II в. до н.э.

Отдельные экземпляры канфаров, сделанные, очевидно, местными мастерами, происходят из таких островных центров, как Лемнос, Хиос, Крит, Родос, Тинос и некоторых других [Savona et al., 1997, p. 223-224, pl. 142,

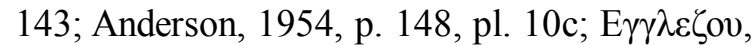
2005, б. 95, 98, pl. 81d; Kallini, 2013, p. 60, 61; Rotroff, 2002, p. 101] где по крайней мере с начала III и до начала II в. до н.э. существовало, пусть и в небольших объемах, производство чернолаковой керамики. К сожалению, эти материалы недостаточно полно опубликованы. Наиболее подробно разработана хро-

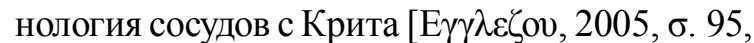
98, pl. 81d]. Судя по степени встречаемости, а также по тому, что они редко покидали пределы мест их изготовления, вряд ли это были серии сосудов, скорее - эпизодический выпуск отдельных форм. Контекст находок позволяет говорить только о датах отдельных вещей, a их небольшое число не дает возможности проследить схему развития формы.

Для Северного Причерноморья, пожалуй, наиболее актуальными являются проблемы датирования так называемых неаттических канфаров классических форм с измененными пропорциями (рис. 3, 4). Это сосуды, отличавшиеся очень высоким и узким горлом, размер которого увеличен за счет максимального уменьшения объема тулова. Тулово может быть как гладким, так и каннелированным, а в некоторых случаях его наличие лишь обозначено в нижней части сосуда. Ножки таких канфаров состоят из профилированного основания малого диаметра и высокого ствола, что делает сосуды крайне неустойчивыми. При этом форма ручек с выступами-шипами в месте верхнего крепления абсолютно аналогична традиционным классическим типам.
А. Божкова выделяет их в один из типов группы Понтийской эллинистической керамики [Bozkova, 1997; 2014, p. 211], поскольку они широко представлены в первую очередь на памятниках Западного и Северо-Западного Причерноморья (Аполлония: [Bozkova, 1997, p. 11, fig. 4];

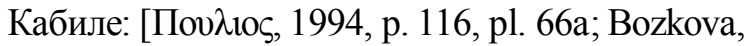
1997a, p. 124, pl. 90-92; 2014, p. 211; Kallini, 2013, p. 60]; Истрия: [Lungu, 2013, p. 290, pl. 25; Kotitsa, 1998, S. 7]; Мессембрия: [Lungu, 2013, p. 206207]; Томы: [Stoian, 1961, fig. 1]; Одессос, Калатис, Тира: [Morel, 2009, p. 159-165]), а также в Ольвии и ее округе [Парович-Пешикан, 1974, c. 78, pис. 75; Handberg et al. 2010, pl. 108; Caмойлова, 2014, с. 405, рис. 1; Ивченко, 2015, рис. 8 ; и др.]. Возможно, по той причине, что их гораздо проще выделить из остальной массы материала, опираясь только на характеристики формы, их чаще фиксируют среди находок неаттических чернолаковых сосудов и на других памятниках северопричерноморского региона, в частности в Херсонесе [Ушаков и др., 2011, с. 134,144 ; Ушакова, 2018, с. 155 , рис. 4,1-4] и в Северо-Западном Крыму: в Керкинитиде [Егорова 2009 , с. 149] и Калос-Лимене [Кемалова и др., 2015, с. 10].

Ранее считалось, что этим в основном и ограничивается их ареал. Так, Ж.-П. Морель, анализируя территорию распространения находок и отчасти степень их концентрации на различных памятниках, упоминает, что такие формы представлены только в Западном Причерноморье, преимущественно на памятниках в Болгарии, а также к югу от этих территорий (на побережье Мраморного моря) и к северу (в Румынии и Украине) [Morel, 2009, p. 159172]. Таким образом, по его мнению, центр фокусируется во Фракии с расширением в две стороны, что позволяет предположить их фракийское происхождение. В настоящий момент мы можем добавить к этому направлению еще одно - в сторону Боспора, поскольку в последние годы такие канфары были обнаружены на территории отдельных боспорских памятников, таких как Пантикапей, поселения Крутой Берег и Сююрташ в Крымском Приазовье, Фанагория и Танаис (рис. 4,5-10). Хотя надо признать, что здесь мы имеем дело все-таки с единичными экземплярами. В других частях эллинского мира такие формы пока не встречались. 
Предположение Ж.-П. Мореля о фракийском происхождении формы, производство которой было налажено в одном или нескольких греческих полисах, поддерживается все большим числом исследователей. В. Лунгу приходит к таким же выводам на основании анализов глин, проведенных П. Дюпоном, но пока опубликована лишь очень небольшая выборка, поскольку основным направлением их исследования было изучение чернолаковой керамики из Истрии с орнаментами в стиле West Slope, среди которой было только несколько фрагментов канфаров соответствующих форм [Lungu, 2013, p. 206-207]. Однако существуют и другие точки зрения. Некоторые исследователи относили такие сосуды предположительно к местному ольвийскому производству [Парович-Пешикан, 1974, с. 79; Bouzek, 1990, p. 54 60; Handberg et al., 2010, p. 185, pl. 108; и др.]. В части работ проскальзывает идея об их малоазийском происхождении [Самойлова, 2014, с. 396]. Принимая во внимание тот факт, что даже беглый взгляд на сами формы и визуальный анализ глин позволяют заметить их большое разнообразие, вряд ли корректно говорить о каком-то одном конкретном производственном центре. Фракийское происхождение, по крайней мере, части их них представляется на данный момент наиболее обоснованным, но не исключает других предположений.

Рассмотрим теперь возможности их датирования, но прежде отметим, что можно выделить минимум три варианта таких канфаров: с гладким туловом (рис. 3,1), каннелированным туловом (рис. 3,2-4) и так называемым «схематизированным» туловом (рис. 3,5,6). Чаще всего при их публикациях приводят очень широкие даты. Однако, изучая комплексы материалов из различных памятников, абсолютно точно можно говорить о том, что в хорошо датированных слоях первых трех четвертей III в. до н.э. такие канфары не встречаются.

В двух первых вариантах (с гладким и каннелированым туловом) развитие формы, на наш взгляд, прослеживается совершенно отчетливо на материалах некрополя Кабиле. В тех случаях, когда погребальные комплексы, включавшие подобные канфары, исследователи имеют возможность датировать достаточно узко на основании данных нумизматики и керамической эпиграфики, можно про- следить трансформацию формы в сторону изменения пропорций (вытягивания профиля и/ или постепенного уменьшения объема тулова) в хронологической последовательности от третьей четверти III до начала - середины II в. до н.э. (рис. $3,1-3$ ).

Если отсеять все публикации канфаров, контекст находок которых невыразителен, то получится, что канфары двух первых вариантов, близкие по пропорциям позднему варианту из некрополя Кабиле, датируются рубежом III-II - первой третью II в. до н.э. Они фиксируются в Мессембрии в слоях конца III в. до н.э. [Bozkova, 2014, p. 211, fig. 29, 30], в Херсонесе с материалами рубежа III-II вв. до н.э. [Ушаков и др., 2011, с. 134, 144], в некрополе Ольвии в погребении с монетой 180-170 гг. до н.э. [Ивченко, 2015, рис. 8], в Аполлонии в слоях первой половины II в. до н.э. [Bozkova, 1997, p. 11, fig. 4] и на территории юго-западной Болгарии с небольшим кладом монет, датированным А. Божковой второй четвертью II в. до н.э. [Bozkova, 2005, p. 47-48]. И только сосуды третьего варианта (с минимальным объемом тулова) на данный момент были обнаружены в том числе и в более поздних слоях, но не позднее третьей четверти II в. до н.э. [Handberg et al., 2010, pl. 108].

Осмелюсь предположить, что первые два варианта развивались синхронно, а третий - это фактически дальнейшее развитие формы более ранних фракийских традиций к полной схематизации тулова, которое происходит к середине или, возможно, третьей четверти II в. до н.э.

Таким образом, необходимо признать, что проблемы датирования неаттических канфаров классических форм еще далеки от разрешения. Выделение большого количества центров их производства только усложняет ситуацию. Однако можно отметить общие тенденции в развитии большинства неаттических сосудов. Вплоть до третьей четверти III в. до н.э. изменения форм в наименьшей степени зависели от места их изготовления и были синхронны и аналогичны аттическими образцам. Существенные изменения начинаются с последней трети III в. до н.э. Только новые исследования и публикации материалов в хорошо датированных контекста позволят уточнить хронологию этих вещей. 


\section{ИЛЛЮСТРАЦИИ}
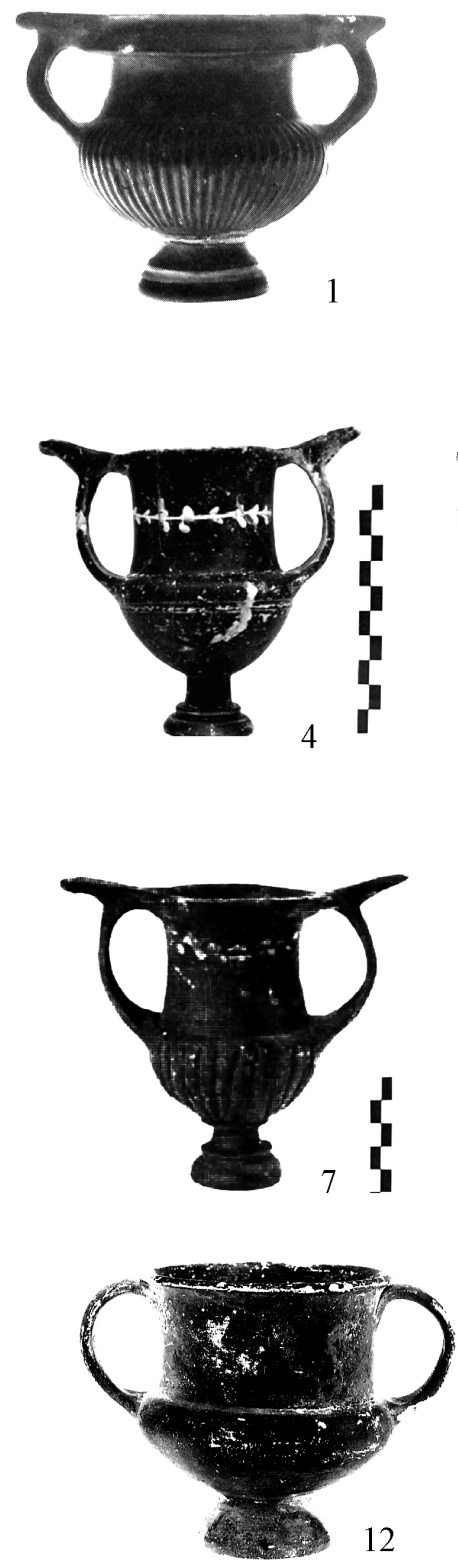
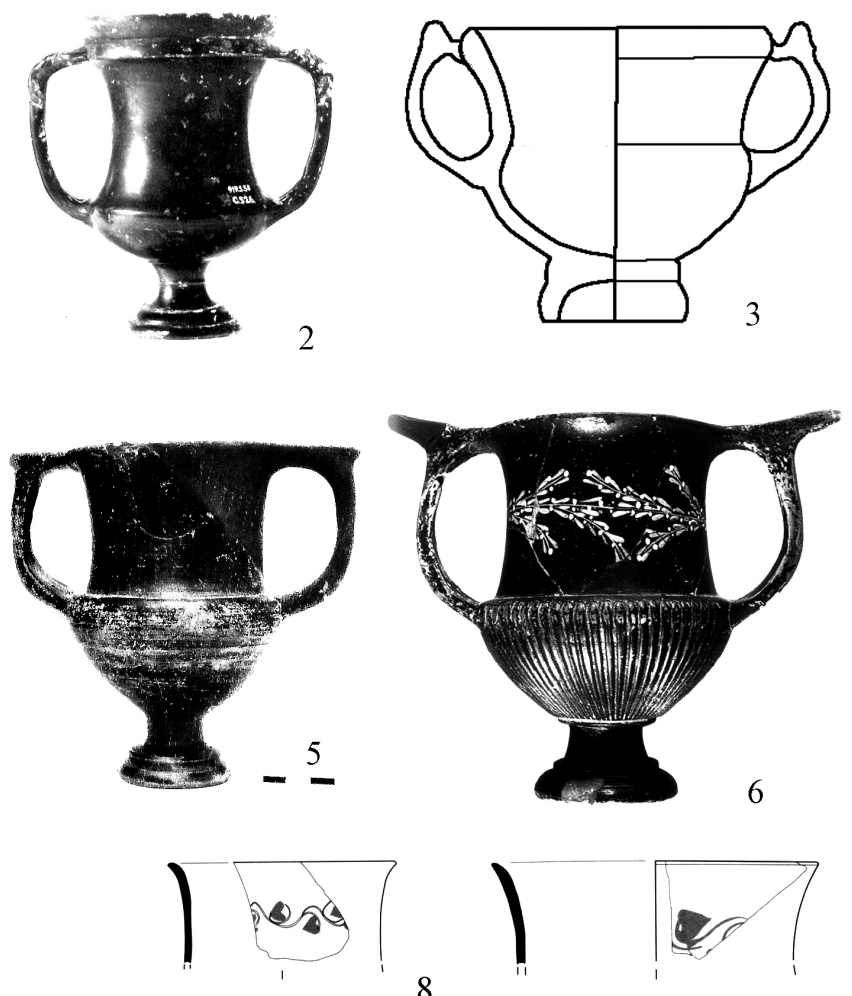

8

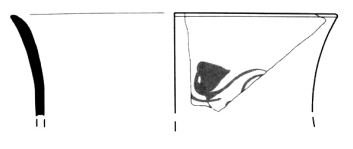

9
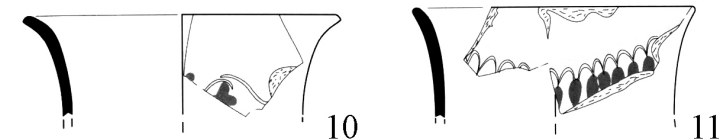

10

11
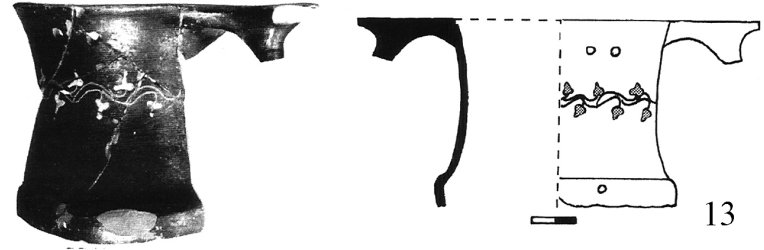

Рис. 1. Неаттические канфары классических форм середины IV - третьей четверти III в. до н.э.:

Апулия: 1 - середина IV в. до н.э. [Hayes, 1984, p. 49,78]; 2 - конец IV - начало III в. до н.э. [Hayes, 1984, p. 69,114];

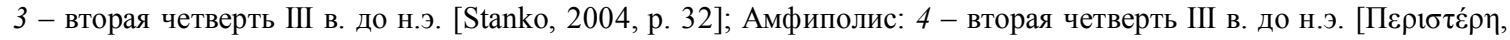

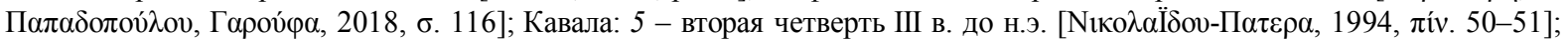

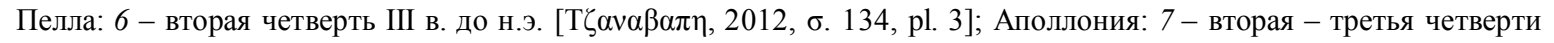
III в. до н.э. [Bozkova 1997, p. 9, fig. 2, 3]; Даскилеон: 8-11 - третья четверть III в. до н.э. [Bulut, 2013, p. 81, fig. 1];

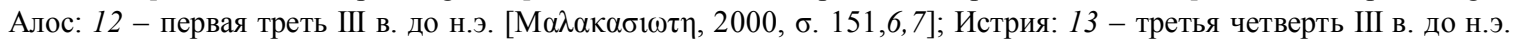

[Lungu, 2013, p. 288, pl. 16]

Fig. 1. Non-attic classical kantharoi of the middle of the $4^{\text {th }}$ - the third quarter of the $3^{\text {rd }} \mathrm{c}$. BC:

Apulia: 1 - the middle of the $4^{\text {th }}$ c. BC [Hayes, 1984, p. 49,78]; 2 - the late $4^{\text {th }}-$ the early $3^{\text {rd }}$ c. BC. [Hayes, 1984, p. 69,114];

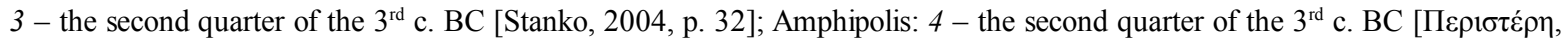

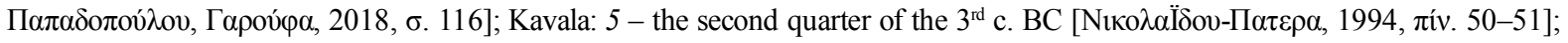
Pella: 6 - the second quarter of the $3^{\text {rd }} \mathrm{c} . \mathrm{BC}[\mathrm{T} \zeta \alpha v \alpha \beta \alpha \pi \eta, 2012, \sigma .134, \mathrm{pl} .3]$; Apollonia: 7 - the second - third quarters of the $3^{\text {rd }}$ c. BC [Bozkova, 1997, p. 9, fig. 2, 3]; Dascylium: $8-11$ - the third quarter of the $3^{\text {rd }}$ c. BC [Bulut, 2013, p. 81, fig. 1]; Alos: 12 - the first third of the $3^{\text {rd }} \mathrm{c}$. BC [M $\left.\alpha \lambda \alpha \kappa \alpha \sigma \omega \tau \eta, 2000, \sigma .151,6,7\right]$; Istria: 13 - the third quarter of the $3^{\text {rd }} \mathrm{c}$. BC [Lungu, 2013, p. 288, pl. 16] 

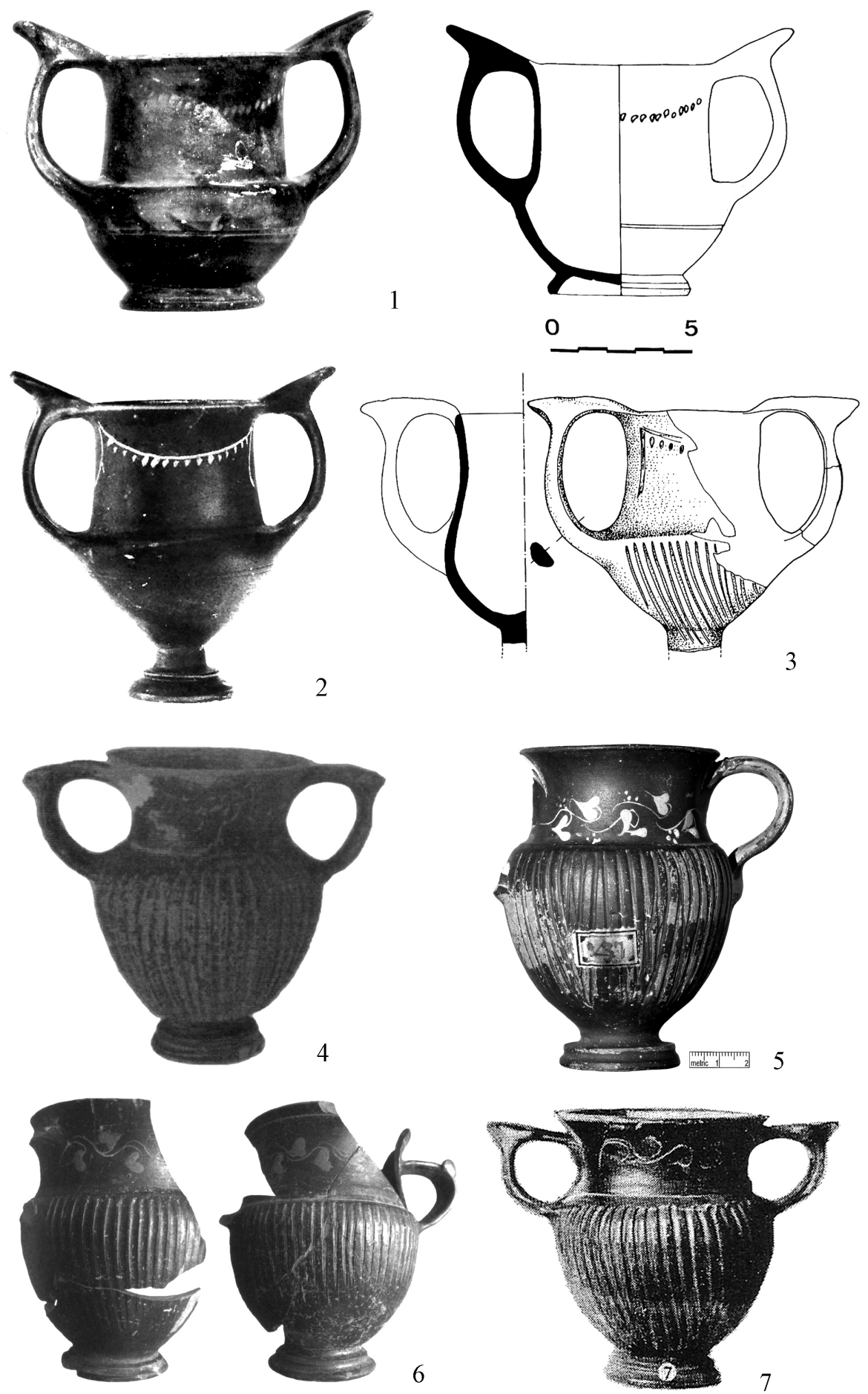

Рис. 2. Неаттические канфары конца III - начала II в. до н.э.:

1 - Македония. Лонгос [Drougou, 1991, p. 129]; 2, 3 - Македония. Бероя [Drougou, Touratsoglou, 1980, p. 100, pl. 66; Поvגıs, 1994, б. 116]; 4 - Западное Причерноморье. Аполлония [Bozkova, 1997, p. 11, fig. 5]; 5 - из фондов ГМИИ им. А.С. Пушкина [Егорова, 2017, табл. 16,18]; 6 - Малая Азия. Даскилеон [Bulut, 2013, p. 81, fig. 1];

7 - Северное Причерноморье. Ольвия [Парович-Пешикан, 1974, с. 79, рис. 75]

Fig. 2. Non-attic kantharoi of the late $3^{\text {rd }}-$ the early $2^{\text {nd }}$ c. BC:

1 - Macedonia. Longos [Drougou, 1991, p. 129]; 2, 3 - Macedonia. Beroea [Drougou, Touratsoglou, 1980, p. 100, pl. 66;

Пov $\lambda_{10}$, , 1994, б. 116]; 4 - the Western Pontic region. Apollonia [Bozkova, 1997, p. 11, fig. 5]; 5 - from the funds of the Pushkin State Museum of Fine Arts [Egorova, 2017, pl. 16,18]; 6 - Asia Minor. Dascylium [Bulut, 2013, p. 81, fig. 1]; 7 - the North Pontic region. Olbia [Parovich-Peshikan, 1974, p. 79, fig. 75] 

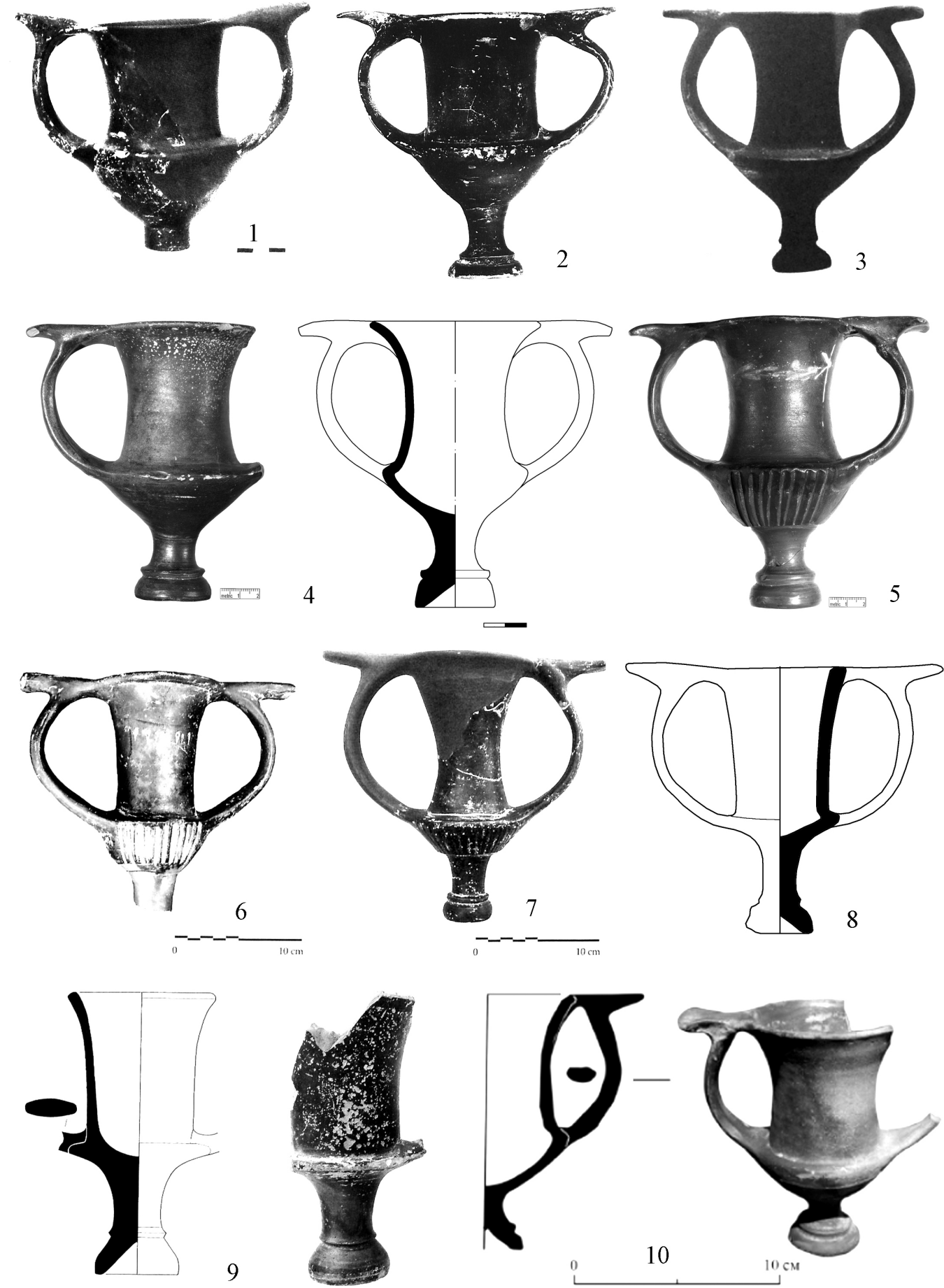

Рис. 3. Неаттические канфары классических форм с измененными пропорциями:

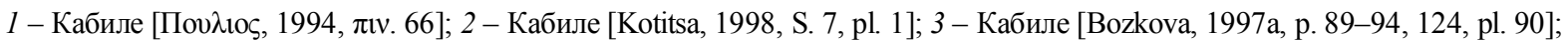
4, 5 - фонды ГМИИ им. А.С. Пушкина [Егорова, 2017, рис. 7, табл. 12, 13,63,64];

6, 7 - фонды музея Несебра [Bozkova, 2014, fig. 29, 30]; 8 - Томис [Stoian, 1961, fig. 1]; 9, 10 - Ольвия [Handberg et al., 2010, pl. 108; Ивченко, 2015, с. 270, рис. 8]

Fig. 3. Non-attic classical kantharoi with modified proportions:

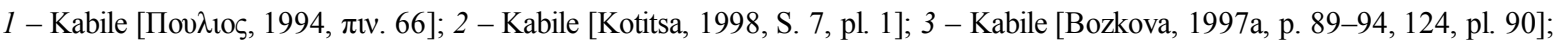
4, 5 - from the funds of the Pushkin State Museum of Fine Arts [Egorova, 2017, fig. 7, pl. 12, 13,63,64];

6, 7 - from the funds of the Museum Ancient Nessebar [Bozkova, 2014, fig. 29, 30]; 8 - Tomis [Stoian, 1961, fig. 1]; 9, 10 - Olbia [Handberg et al., 2010, pl. 108; Ivchenko, 2015, p. 270, fig. 8] 

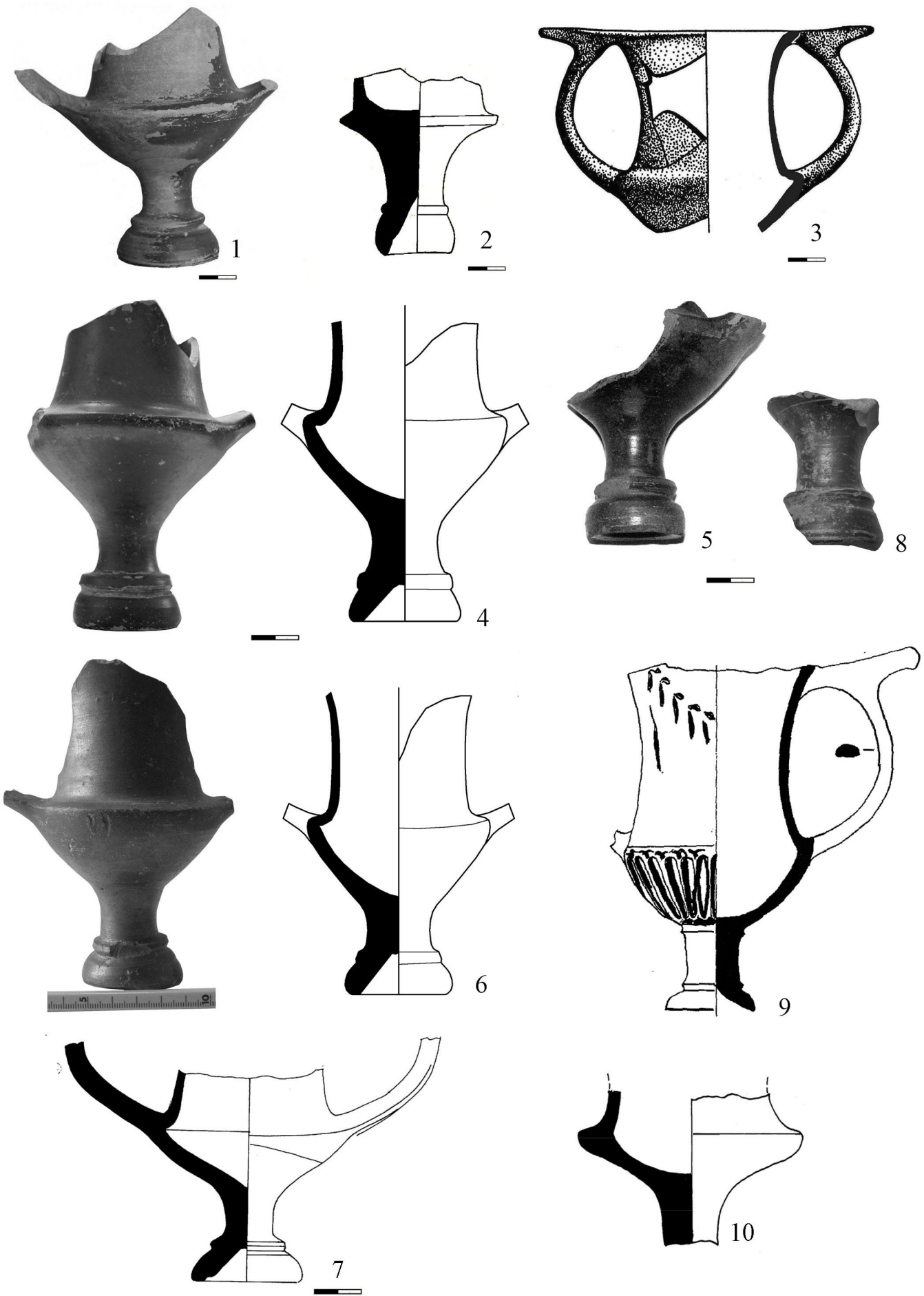

Рис. 4. Неаттические канфары классических форм с измененными пропорциями:

1, 2 - Херсонес [Ушаков и др., 2011, с. 134; Белов, 1964, с. 247, рис. 7]; 3 - Керкинитида [Егорова, 2009, с. 149]; 4-7 - Пантикапей; 8 - Танаис; 9 - Сююрташ [Масленников, 2016, рис. 4, 8]; 10 - Крутой берег [Масленников, 2016a, с. 56]

Fig. 4. Non-attic classical kantharoi with modified proportions:

1, 2 - Chersonesos [Ushakov et al., 2011, p. 134; Belov, 1964, p. 247, fig. 7]; 3 - Kerkinitis [Egorova, 2009, p. 149]; 4-7 - Pantikapaeum; 8 - Tanais; 9 - Suurtash [Maslennikov, 2016, fig. 4, 8];

10 - Krutoy bereg [Maslennikov, 2016a, p. 56] 


\section{СПИСОК ЛИТЕРАТУРЫ}

Белов Г. Д., 1964. Раскопки в Херсонесе в 1961 г. // Сообщения Государственного Эрмитажа. Вып. XXV. C. 62-65.

Буравчук О. Е., 2014. Эллинистическая расписная керамика // Материалы по археологии, истории и этнографии Таврии. Suppl. 13. С. 357-379.

Егорова Т. В., 2000. Чернолаковые канфары с городища «Чайка» // Российская археология. № 4. C. $137-151$.

Егорова Т. В., 2009. Чернолаковая керамика IV-II вв. до н.э. с памятников Северо-Западного Крыма. М. : Изд-во МГУ. 253 с.

Егорова Т. В., 2017. К вопросу о датировке S-видных эллинистических канфаров // Античные реликвии Херсонеса: открытия, находки, теории. Саки : Бровко А.А. С. 73-79.

Зайцев Ю. П., 1998. Керамика с лаковым покрытием из слоя пожара 1 Южного дворца Неаполя Скифского // Эллинистическая и римская керамика в Северном Причерноморье. М. : Изд-во ГИМ. С. 52-60. Труды ГИМ; вып. 102.

Ивченко А. В., 2015. Склеп с паросской амфорой на некрополе Ольвии // Античный мир и археология. Вып. 17. С. 253-271.

Кемалова А. Р., Гарипов А. С., Смекалова Т. Н., Пасуманский А. Е., Кецко Р. С., 2015. Античные памятники Тарханкута. СПб. : Волна. 160 с.

Лепер Р. Х., 1927. Дневник раскопок некрополя // Херсонесский сборник. Вып. II. С. 189-256.

Лимберис Н. Ю., Марченко И. И., 2017. Атрибуция и хронология чернолаковых канфаров из меотских памятников Прикубанья // Stratum plus. № 3. С. 181-198.

Масленников А. А. 2016. Керамика с лаковым покрытием из раскопок городища Сююрташ // Древности Боспора. Т. 20. С. 330-349.

Масленников А. А., 2016а. Керамика с лаковым покрытием из раскопок городища «Крутой Берег» в крымском Приазовье // Вестник Нижегородского университета. № 1. С. 51-58.

Парович-Пешикан М., 1974. Некрополь Ольвии эллинистического времени. Киев : Наукова думка. 219 с.

Самойлова Т. Л., 2014. Буролаковая керамика // Материалы по археологии, истории и этнографии Таврии. Suppl. 13. С. 395-409.

Сапрыкин С. Ю., Внуков С. Ю., 2015. Греческие надписи из Кара-Тобе (Северо-Западный Крым) // Вестник древней истории. № 2. С. 98-119.

Ушаков С. В., Дюженко Т. В., Лесная Е. С., Тюрин М. И., 2011. Комплекс эллинистического времени из раскопок колодца в алтарной части базилики «Крузе» (предварительная информация по материалам работ 2009-2010 гг.) // Причер- номорье. История, политика, культура. Вып. V (II). Серия А. С. 129-149.

Ушакова К. С., 2018. Чернолаковая керамика из раскопок Р.Х. Лепера в северо-восточном районе Херсонеса Таврического // Ученые записки Крымского федерального университета им. В.И. Вернадского. Серия «Исторические науки». Т. 4 (70), № 2. С. 148-165.

Anderson J. K., 1954. Excavations on the Kofina Ridge, Chios // Annual of the British School at Athens. № 49. P. 123-172.

Behr D., 1988. Neue Ergebnisse zur pergamenischen Westabhangkeramik // Istanbuler Mitteilungen. Vol. 38. P. 97-178.

Bouzek, J., 1990. Studies of Greek pottery in the Black Sea area. Prague : Charles University. 196 p.

Bozkova A., 1997. A Pontic Pottery Group of the Hellenistic Age. A Survey Based on Examples from the Bulgarian Black Sea Coast // Archaeologia Bulgarica. № 2. P. 8-17.

Bozkova A., 1997a. La ceramique des necropolis hellenistiques de Cabyle // $\Delta^{\prime} \mathrm{E} \pi \iota \tau \eta \mu$ ovıкท́ $\Sigma$ v-

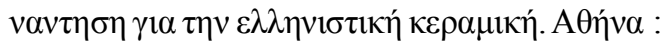
Comteko Е.П.Е. P. 123-127.

Bozkova A., 2005. Hellenistic Cantharoi from SouthWestern Bulgaria // Studia Archaeologica Universitatis Serdicensis. Suppl. IV. Sofia : Св. Климент Охридски. Р. 46-51.

Bozkova A., 2014. West Slope Pottery from Mesambria Pontike // Pottery, Peoples and Places. Study and Interpretation of Late Hellenistic Pottery. Black Sea Studies. № 16. Aarhus : University Press. P. 199-214.

Bulut H., 2013. West Slope Ware from Daskyleion // Istanbuler Mitteilungen. № 63. P. 75-127.

Domżalski K., 2007. Changes in Late Classical and Hellenistic Fine Pottery Production in the Eastern Mediterranean as Reflected by Imports in the Pontic Area // The Black Sea in Antiquity. Regional and Interregional Economic Exchanges. Aarhus : University Press. P. 161-181.

Drougou S., 1991. Hellenistic Pottery from Macedonia. Thessaloniki : T. Alintzis. $173 \mathrm{p}$.

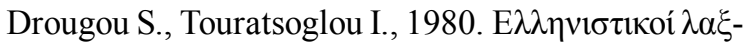

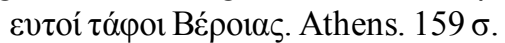

Drougou S., Touratsoglou I., 1991. Hellenistische keramik aus Makedonien: chronologische indizien // Antike Kunst. № 34. P. 13-27.

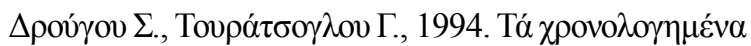

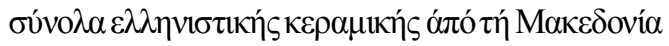

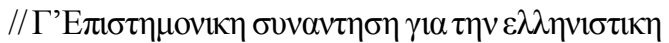

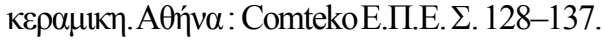

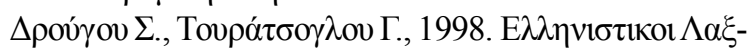

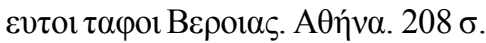

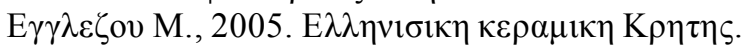
A $\theta$ ท́va. 258 б. 
Handberg S., Petersen J. H., Bilde P. G., Højberg Bjerg J.M., Samojlova T.L., 2010. Glossed Pottery // The Lower City of Olbia (Sector NGS) in the $6^{\text {th }}$ Century BC to the $4^{\text {th }}$ Century AD. In 2 vols. Vol. 1. Aarhus : University Press. P. $185-261$.

Hannestad L., Stolba V. F., Hastrup H. B., 2002. BlackGlazed. Red-Figure and Grey Ware Pottery. Panskoye I // The Monumental Building U6. Vol. 1. Aarhus : University Press. P. 127-149.

Hayes J. W., 1984. Greek and Italian Black-Gloss Wares and Related Wares in the Royal Ontario Museum: a Catalogue. Toronto : Royal Ontario Museum. $204 \mathrm{p}$.

Japp S., 2009. Archäometrisch-archäologische Untersuchungen an Keramik aus Pergamon und Umgebung // Istanbuler Mitteilungen. Bd. 59. Tübingen : [s. n.]. P. 193-268.

Kallini Ch., 2013. Hellenistic Kantharoi, Their Production Centres and Their Distribution in the Eastern Mediterranean // British Archaeological Reports 2593. Networks in the Hellinistic World. According to the Pottery in the Eastern Mediterranean and Beyond. P. 59-66.

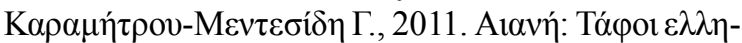

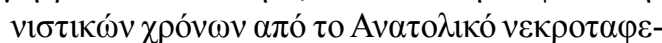

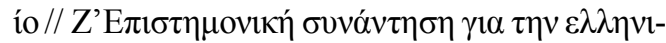

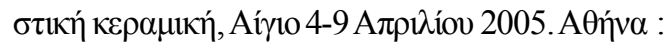
Comteko Е.П.Е. Г. 407-420.

Kotitsa Z., 1998. Hellenistische Keramik im Martin von Wagner Museum der Universität Würzburg. Würzburg : Ergon-Verlag. 167 p.

Lungu V., 2013. La céramique de style west slope // Histria. Les résultats des fouilles. XIV. Bucarest, Paris. 307 p.

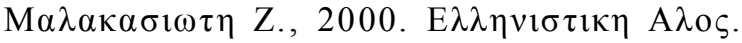

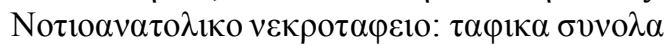

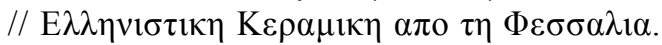
A $\theta \eta ́ v \alpha:$ Bòos. $\Sigma . ~ 147-155$.

Morel J.-P., 1987. La Céramique à vernis noir en Italie Septentrionale // Celti ad Etruschi. Bologna : University press. P. 113-134.

Morel J.-P., 2009. Observations sur les faciès régionaux ou locaux des céramiques du Pont-Euxin (IVeIer siècle avant J.-C.) // Il Mar Nero 6, 2004/2006. Actes du colloque international "Les productions céramiques du Pont-Euxin à l'époque grecque”. Bucarest. P. 159-173.

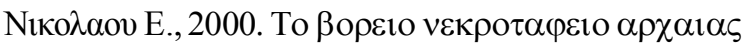

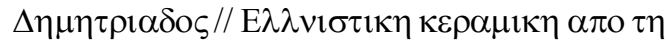

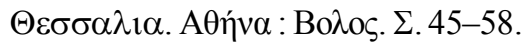

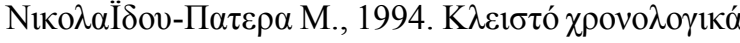

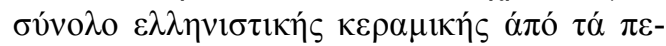

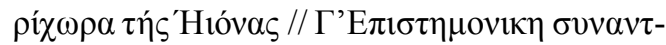
$\eta \sigma \eta \gamma 1 \alpha \tau \eta \nu \varepsilon \lambda \lambda \eta v i \sigma \tau 1 \kappa \eta \kappa \varepsilon \rho \alpha \mu 1 \kappa \eta$. А $\theta \eta \dot{v} \alpha \alpha$ : Comteko Е.П.Е. $\Sigma$. 104-114.

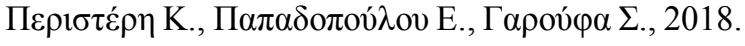

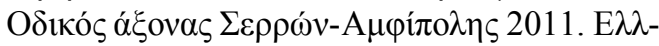

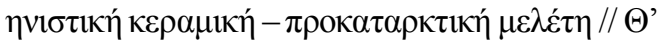

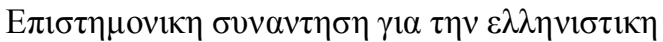

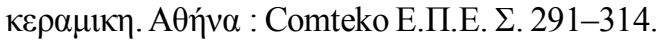

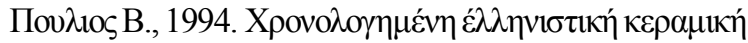

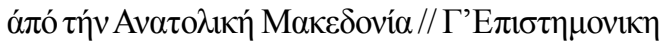

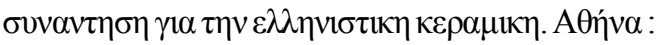
ComtekoЕ.П.Е. ¿. 115-127.

Robinson D. M., 1950. Excavations at Olynthus. Part XIII. Baltimore : Johns Hopkins Press. 463 p.

Rotroff S. I., 1984. Spool Saltcellars in the Athenian Agora // Hesperia. Vol. 53, № 3. P. 343-355.

Rotroff S.I., 1997. Hellenistic Pottery. Athenian and Imported Wheelmade Table Ware and Related Material // The Athenian Agora. Vol. XXIX. Princeton; New Jersey : The American School of Classical Studies at Athens. 612 p.

Rotroff S. I., 2002. West Slope in the East// Productions et diffusion en Méditerranée orientale, Chypre, Égypte et côte syro-palestinienne. Céramiques hellénistiques et romaines. Lyon. P. 97-116.

Savona S., Poggessi G., Monaco M. Ch., Monaco M. C., 1997. Un deposito di ceramiche tardoclassiche ed ellenistiche del cabirio Di Lemno: analisi delle forme // $\Delta^{\prime} \mathrm{E} \pi \imath \sigma \tau \eta \mu о \nu \imath \kappa \eta \Sigma v v \alpha \nu \tau \eta \sigma \eta \gamma \imath \alpha \tau \eta \nu$

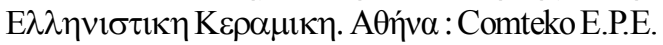
P. 220-231.

Schäfer J., 1968. Hellenistische Keramik aus Pergamon // Pergamenische Forschungen. Bd. 2. Berlin : De Gruyter. $161 \mathrm{p}$.

Sökeli H., 2013. Ceramic Workshops in Hellenistic and Roman Anatolia: Production Characteristics and Regional Comparisons. Ankara : Department of Archaeology Ġhsan Doğramacı Bilkent University. $132 \mathrm{p}$.

Sparkes B. A., Talcott L., 1970. Black and Plain Pottery of the $6^{\text {th }}, 5^{\text {th }}, 4^{\text {th }}$ Centuries B.C. $/ /$ The Athenian Agora. Vol. XII. New Jersey; Princeton : The American School of Classical Studies at Athens. $466 \mathrm{p}$.

Stanko E.A., 2004. La ceramica a vernice nera della stipe di Lucus Feroniae, analisi preliminare // Bullettino della Commissione Archeologica Comunale di Roma CV. Roma : L'Erma. P. 29-47.

Stoian I., 1961. La città Pontica di Tomis // Dacia. Vol. 5. P. 233-274.

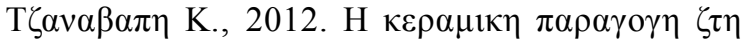

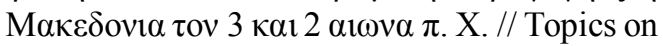
Hellenistic Pottery in Ancient Macedonia. Athens : [s. n.]. P. 126-157.

\section{REFERENCES}

Belov G.D., 1964. Excavations in Chersonesos in 1961. Soobshcheniya Gosudarstvennogo Ermitazha, iss. XXV, pp. 62-65. (in Russian). 
Buravchuk O.E., 2014. Hellenistic Painted Pottery. Materialy po arheologii, istorii $i$ ehtnografii Tavrii, Suppl. 13, pp. 357-379. (in Russian).

Egorova T.V., 2000. Black-Glazed Kantharos from Chaika Settlement. Rossiyskaya arkheologiya, no. 4, pp. 137-151. (in Russian).

Egorova T.V., 2009. Black-Glazed Pottery of the $I V$ II Cent. BC from the North-Western Crimea Sites. Moscow, MSU. 253 p. (in Russian).

Egorova T.V., 2017. The Problem of the Chronology of Hellenistic S-Shaped Kantharoi. Ancient Relics of Chersonese: Openings to Notions. Proceedings of the International Academic Conference Sevastopol, 10-12 October 2017. Saky, IP Brovko A.A. Publ., pp. 73-79. (in Russian).

Zaycev Yu.P., 1998. Lacquered Ceramics from the Fire Layer 1 of the South Palace of Scythian Naples. Hellenistic and Roman Pottery in Northern Pontic. Trudy GIM, iss. 102. Moscow, SHM, pp. 52-60. (in Russian).

Ivchenko A.V., 2015. The Crypt with the Parossian Amphora on the Necropolis of Olbia. Antichnyy mir $i$ arheologiya, iss. 17, pp. 253-271. (in Russian).

Kemalova A.R., Garipov A.S., Smekalova T.N., Pasumanskiy A.E., Kecko R.S., 2015. Antique sites of Tarkhankut. Saint-Petersburg, Volna Publ. 160 p. (in Russian).

Leper R.H., 1927. Diary of the Necropolis Excavations. Hersonesskiy sbornik, iss. II, pp. 189-256. (in Russian).

Limberis N.Yu., Marchenko I.I., 2017. Attribution and Chronology of Black-Glazed Kantharoi from Maeotian Monuments of Kuban Region. Stratum plus, no. 3, pp. 181-198. (in Russian).

Maslennikov A.A., 2016. Ceramics Lacquered from the Excavation of the Syuurtash Settlement. Drevnosti Bospora, vol. 20, pp. 330-349. (in Russian).

Maslennikov A.A., 2016a. Black-Glazed pottery from the excavation of the settlement "Krutoy Bereg" in the Crimean Azov Sea Region. Vestnik Nizhegorodskogo universiteta, no. 1, pp. 5158. (in Russian).

Parovich-Peshikan M., 1974. Necropolis of Olbia in Hellenistic time. Kiev, Naukova dumka Publ. 219 p. (in Russian).

Samoylova T.L., 2014. Brown-Gloss pottery. Materialy po arheologii, istorii i ehtnografii Tavrii, Suppl. 13, pp. 395-409. (in Russian).

Saprykin S.Yu., Vnukov S.Yu., 2015. Greek inscriptions from Kara-Tobe (North-Western Crimea). Journal of Ancient History, no. 2, pp. 98-119. (in Russian).

Ushakov S.V., Dyuzhenko T.V., Lesnaya E.S., Tyurin M.I., 2011. The Complex of the Hellenistic Time from the Excavation of the Well in the Altar Part of the Basilica "Kruse" (Preliminary Information on the Materials of Works 2009-2010). Prichernomor'e. Istoriya, politika, kul'tura, iss. V(II), series A, pp. 129-149. (in Russian).

Ushakova K.S., 2018. Black-Glazed Pottery from the Excavation of R.Kh. Leper in the North-Eastern Region of Tauric Chersonesos. Uchenye zapiski Krymskogo federal'nogo universiteta imeni V.I. Vernadskogo. Seriya "Istoricheskie nauki", vol. 4 (70), no. 2, pp. 148-165. (in Russian).

Anderson J.K., 1954. Excavations on the Kofina Ridge, Chios. Annual of the British School at Athens, no. 49, pp. 123-172.

Behr D., 1988. Neue Ergebnisse zur pergamenischen Westabhangkeramik. Istanbuler Mitteilungen, vol. 38, pp. 97-178.

Bouzek, J., 1990. Studies of Greek pottery in the Black Sea area. Prague, Charles University. 196 p.

Bozkova A., 1997. A Pontic Pottery Group of the Hellenistic Age. A Survey Based on Examples from the Bulgarian Black Sea Coast. Archaeologia Bulgarica, no. 2, pp. 8-17.

Bozkova A., 1997a. La ceramique des necropolis

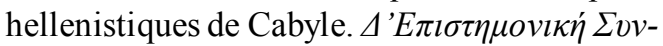

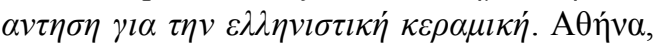
Comteko Е.П.Е., pp. 123-127.

Bozkova A., 2005. Hellenistic Cantharoi from SouthWestern Bulgaria. Studia Archaeologica Universitatis Serdicensis, Suppl. IV. Sofia, University Press “St. Kliment Ohridski”, pp. 46-51.

Bozkova A., 2014. West Slope Pottery from Mesambria Pontike. Pottery, Peoples and Places. Study and interpretation of late Hellenistic pottery. Black Sea Studies, no. 16. Aarhus, University Press, pp. 199-214.

Bulut H., 2013. West Slope Ware from Daskyleion. Istanbuler Mitteilungen, no. 63, pp. 75-127.

Domżalski K., 2007. Changes in late Classical and Hellenistic Fine Pottery Production in the Eastern Mediterranean as Reflected by Imports in the Pontic Area. The Black Sea in Antiquity. Regional and Interregional Economic Exchanges. Aarhus, University Press, pp. 161-181.

Drougou S., 1991. Hellenistic Pottery from Macedonia. Thessaloniki. $173 \mathrm{p}$.

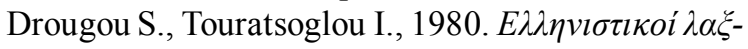

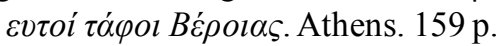

Drougou S., Touratsoglou I., 1991. Hellenistische keramik aus Makedonien: chronologische indizien. Antike Kunst, no. 34, pp. 13-27.

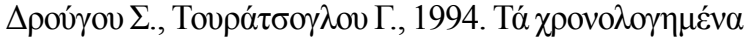

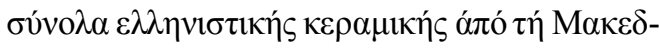

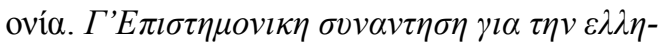

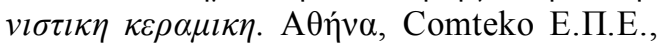
pp. 128-137. (in Greek). 


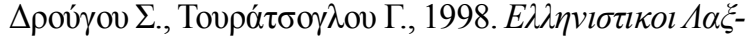

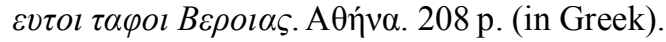

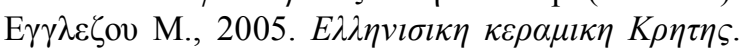
Athens. 258 p. (in Greek).

Handberg S., Petersen J.H., Bilde P.G., Højberg Bjerg J.M., Samojlova T.L., 2010. Glossed pottery. The Lower City of Olbia (Sector NGS) in the 6th Century $B C$ to the 4th Century $A D$, vol. 1. Aarhus, University Press, pp. 185-261.

Hannestad L., Stolba V.F., Hastrup H.B., 2002. BlackGlazed. Red-Figure and Grey Ware Pottery. Panskoye I. The Monumental Building U6, vol. 1. Aarhus, University Press, pp. 127-149.

Hayes J.W., 1984. Greek and Italian Black-Gloss Wares and Related Wares in the Royal Ontario Museum: a Catalogue. Toronto, Royal Ontario Museum. 204 p.

Japp S., 2009. Archäometrisch-archäologische Untersuchungen an Keramik aus Pergamon und Umgebung. Istanbuler Mitteilungen, band 59. Tübingen, pp. 193-268.

Kallini Ch., 2013. Hellenistic Kantharoi, Their Production Centres and Their Distribution in the Eastern Mediterranean. British Archaeological Reports, no. 2593. Networks in the Hellinistic World. According to the Pottery in the Eastern Mediterranean and Beyond, pp. 59-66.

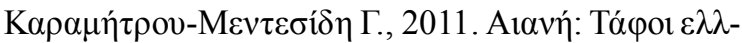

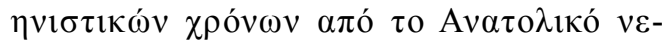

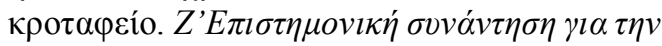

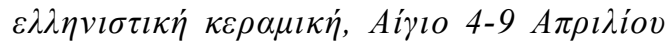
2005. A $\theta$ vo, Comteko E.П.Е., pp. 407-420. (in Greek).

Kotitsa Z., 1998. Hellenistische Keramik im Martin von Wagner Museum der Universität Würzburg. Würzburg, Ergon-Verlag, 167 p.

Lungu V., 2013. La céramique de style west slope. Histria. Les résultats des fouilles, XIV. Bucarest, Paris. 307 p.

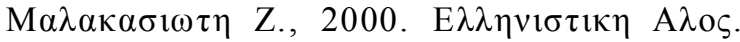

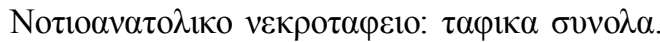

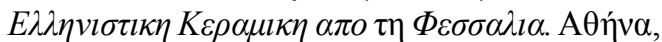
Bòos, pp.147-155. (in Greek).

Morel J.-P., 1987. La Céramique à vernis noir en Italie Septentrionale. Celti ad Etruschi. Bologna, University Press, pp. 113-134.

Morel J.-P., 2009. Observations sur les faciès régionaux ou locaux des céramiques du Pont-Euxin (IVeIer siècle avant J.-C.). Il Mar Nero 6, 2004/2006. Actes du colloque international «Les productions céramiques du Pont-Euxin à l'époque grecque». Bucarest, pp. 159-173.

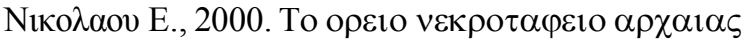

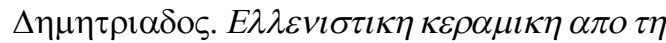
$\Theta \varepsilon \sigma \sigma \alpha \lambda \iota \alpha$. A $\theta \eta \dot{v} \alpha$, Bòos Publ., pp. 45-58. (in Greek).

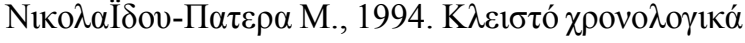

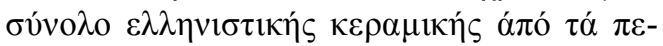

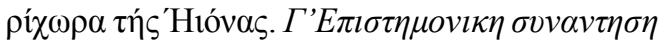
$\gamma \iota \alpha \tau \eta v \varepsilon \lambda \lambda \eta v \imath \sigma \tau \iota \kappa \eta \kappa \varepsilon \rho \alpha \mu \iota \kappa \eta$. A $\theta \eta \dot{v} \alpha$, Comteko Е.П.Е., pp. 104-114. (in Greek).

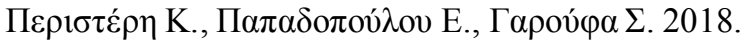

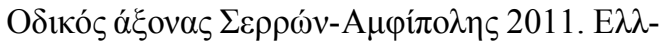

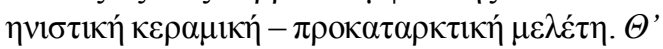

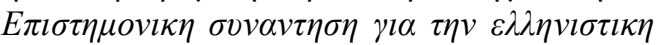

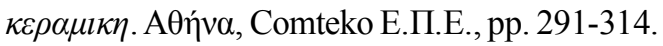
(in Greek).

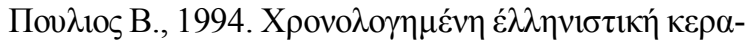

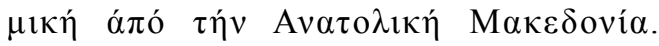
$\Gamma^{\prime} E \pi \imath \sigma \tau \eta \mu о v \iota \kappa \eta \sigma v v \alpha v \tau \eta \sigma \eta \gamma \iota \alpha \tau \eta v \varepsilon \lambda \lambda \eta v \imath \sigma \tau \iota \kappa \eta$ $\kappa \varepsilon \rho \alpha \mu \iota \kappa \eta$. А $\theta \eta ́ v \alpha$, Comteko Е.П.Е., pp. 115-127. (in Greek).

Robinson D.M., 1950. Excavations at Olynthus. Part XIII. Baltimore, Johns Hopkins Press. 463 p.

Rotroff S.I., 1984. Spool Saltcellars in the Athenian Agora. Hesperia, vol. 53, no. 3, pp. 343-355.

Rotroff S.I., 1997. Hellenistic pottery. Athenian and imported wheelmade table ware and related material. The Athenian Agora, vol. XXIX. Princeton, New Jersey, The American School of Classical Studies at Athens. 612 p.

Rotroff S.I., 2002. West Slope in the East. Productions et diffusion en Méditerranée orientale, Chypre, Égypte et côte syro-palestinienne. Céramiques hellénistiques et romaines, Lyon, pp. 97-116.

Savona S., Poggessi G., Monaco M.Ch., Monaco M.C., 1997. Un deposito di ceramiche tardoclassiche ed ellenistiche del cabirio Di Lemno: analisi delle forme.

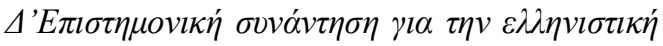

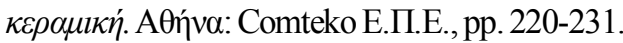

Schäfer J., 1968. Hellenistische Keramik aus Pergamon. Pergamenische Forschungen, band 2. Berlin, De Gruyter, $161 \mathrm{p}$.

Sökeli H., 2013. Ceramic workshops in Hellenistic and Roman Anatolia: production characteristics and regional comparisons. Ankara, Department of Archaeology Ġhsan Doğramacı Bilkent University. $132 \mathrm{p}$.

Sparkes B.A., Talcott L., 1970. Black and Plain Pottery of the 6th, 5th, 4th Centuries B.C. The Athenian Agora, vol. XII. New Jersey, Princeton, The American School of Classical Studies at Athens. $466 \mathrm{p}$.

Stanko E.A., 2004. La ceramica a vernice nera della stipe di Lucus Feroniae, analisi preliminare. Bullettino della Commissione Archeologica Comunale di Roma CV. Roma, L'Erma, p. 29-47.

Stoian I., 1961. La città Pontica di Tomis. Dacia, vol. 5 , pp. 233-274.

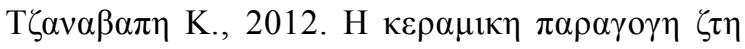

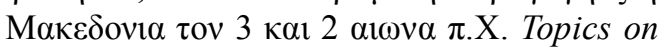
Hellenistic pottery in Ancient Macedonia. Athens, pp. 126-157. (in Greek). 
T.B. Егорова. Проблемы датирования неаттических канфаров классических форм

\section{Information about the Author}

Tatyana V. Egorova, Candidate of Sciences (History), Researcher, Department of Archaeology, Lomonosov Moscow State University, Prosp. Lomonosova, 27, 4, 119192 Moscow, Russian Federation, tvegorova@yandex.ru, https://orcid.org/0000-0002-8479-0518

\section{Информация об авторе}

Татьяна Валерьевна Егорова, кандидат исторических наук, научный сотрудник кафедры археологии, Московский государственный университет им. М.В. Ломоносова, просп. Ломоносовский, 27, корпус 4, 119192 г. Москва, Российская Федерация, tvegorova@yandex.ru, https://orcid.org/ 0000-0002-8479-0518 